EISSN: 2706-7955 ISSN: 2077-4605

DOI: $10.36632 /$ mejar/2021.10.2.46

Journal homepage: www.curresweb.com

Pages: 629-636

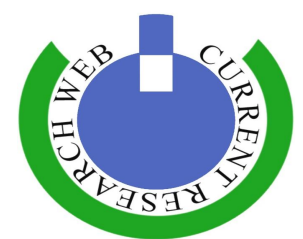

\title{
Effect of Foliar Application of Yeast (Saccharomyces Cescervisiae) on Controlling Downy Mildew Disease and Yield Production of Onion
}

\author{
Abd-Elbaky A.A., Yousef H. and Abd El-Maged M.S.
}

Plant Pathology Research Institute, Agricultural Research Center, Giza, Egypt.

\author{
Received: 11 April 2021 \\ Accepted: 20 May 2021 \\ Published: 30 May 2021
}

\begin{abstract}
The efficiency of foliar application of Saccharomyces cescervisiae yeast extract at different concentrations was evaluated for controlling onion downy mildew disease and increasing onion bulb yield under natural infection conditions during two successive seasons (2017/2018 and 2018/2019). Treatment with yeast extracts showed a significant reduction of downy mildew severity, incidence and increased onion bulb yield when compared to untreated control during the two growing seasons as well. Concentrations of yeast extract were found to be directly proportional to disease severity and percentage of downy mildew. Moreover, plant length and fresh weight as well as bulb yield were also increased in comparison with control. The treatments increased the activity of peroxidase and polyphenol oxidase, beside an increase in total carbohydrates and total phenolic contents especially at concentrations of 5 and $10 \mathrm{~g} / \mathrm{L}$. The tested concentrations of yeast extract had a direct effect on increasing the production of chlorophyll A and B as well as carotenoids compared with control during the two successive growing seasons.
\end{abstract}

Keywords: onion, yeast extract, Saccharomyces cescervisiae, downy mildew, biochemical changes, yield production.

\section{Introduction}

Onion (Allium cepa L.) is an important crop in Egypt for local consumption and for exportation. The total cultivated area with onion crop in Egypt was 190628 feddan which yielded 2857337 tonnes in 2018 (Anonymous, 2018) according to the Statistical Department of Ministry of Agriculture and Land Reclamation.

Onion is one of the most commercially valuable vegetables owing to its flavor and healthpromoting properties such as anticancer properties, antithrombotic, antiasthmatic activity and antibiotic effects (Suleria et al., 2015). Egyptian onion varieties have exceptionally high quality due to their high nutritional value and pungency, and hence have a high export potential.

Foliar diseases play a key role in decreasing bulb yield and production quality in commercial onion cultivation. Downy mildew is among these foliar diseases which affects leaves and bulbs and is caused by Peronospora destructor (Berk). The severity of this disease varies considerably based on locality and season, as well as how much and for how long onion foliage is wet (Gupta et al., 2012). Downy mildew is a major leaf disease that affects onion bulb production as well as onion seeds production (Schwartz and Mohan, 2008). Onion bulbs yield decline due to downy mildew outbreaks can range from $30 \%$ up to $70 \%$ when the environment is favorable for disease spread. For seed production cultivation, $P$. destructor reduces yield dramatically, with $60-70 \%$ losses as reported in India by Ankita et al., (2020). Furthermore, possibly infected seeds with P. destructor may serve as primary inoculum for the following season. Therefore, adequate control of downy mildew highly recommended (Sharma et al., 2002).

Biological control of different plant diseases has mainly focused on using bacteria or filamentous fungi (Yousef, 2021). Recently, several studies applied yeasts as biocontrol agents against different plant pathogens (El-Sharkawy et al., 2015).

Corresponding Author: Heba Yousef, Plant Pathology Research Institute, Agricultural Research Center, Giza, Egypt. E-mail: heba.yousef@live.com 
Yeasts have been used for food and beverage production for thousands of years, they are consumed directly as food supplements, and widely employed in the food industry (Bekatorou et al., 2006). This may explain why yeasts are commonly considered safe, so using them in crops and on food products triggers less alarm than using bacteria or filamentous fungi (EFSA, 2005).

To effectively develop and apply yeast as a plant protection bioagent, the mechanisms responsible for its biocontrol activity must be understood (Spadaro and Droby, 2016). These mechanisms include competition for nutrients and space, secretion of enzymes, toxin production, mycoparasitism and induction of resistance in plants (Wisniewski and Droby, 2012).

As plant growth promoters, yeasts have improved vegetative characteristics especially when yeast extracts were sprayed on garlic and onion plants (Shafeek et al., 2015). Similarly, Shalaby and El-Nady (2008) studied the potential use of yeasts as biocontrol agents for soil-borne fungal plant pathogens, post-harvest diseases control and as plant growth promoters. Saccharomyces cerevisiae yeast isolates significantly decreased powdery mildew disease incidence (El-Sayed and Farrag, 2011).

The objective of this study is to evaluate the efficiency of foliar application of Saccharomyces cescervisiae yeast extract as an environmentally friendly control measure of onion downy mildew disease and its effect on chemical properties, vegetative characteristics, and yield production of onion under natural field conditions.

\section{Materials and Methods}

\subsection{Field experiment}

Field experiment was carried out at Qalyubia governorate, Egypt, during two successive seasons 2017/2018 and 2018/2019. The experiment aimed to evaluate the efficiency of different yeast concentrations as biocontrol agents on onion downy mildew disease severity, disease incidence and as a plant growth promoter of onion plants under natural infections.

\subsubsection{Experimental design}

A completely randomized plot design with three replicates (plots) was used. The plot area was $3.0 \times 3.5 \mathrm{~m}\left(10.5 \mathrm{~m}^{2}=1 / 400\right.$ feddan). 60 -day-old seedlings of onion $\mathrm{cv}$. (Behery) were planted per each plot at spacing $10 \mathrm{~cm} \times 10 \mathrm{~cm}$, onions were grown under recommended irrigation, fertilizer, and pest management practice rules.

\subsubsection{Application of yeast extract on onion}

Dry yeast (Saccaromyces cescervisiae) was obtained from Egyptian Sugar and Integrated Industries Company (ESIIC), Giza- Egypt. Yeast extract was prepared according to the method of Morsi et al., (2008) by dissolving an amount of dry yeast in water followed by adding sugar at a ratio of 1:1 and kept for 24 hours in a warm place for reproduction. Four different concentrations of yeast extract $(1,2,5$ and $10 \mathrm{~g} / \mathrm{L})$ were used.

After 60 days from transplanting, onion plants were sprayed with the previously prepared different yeast solutions. This was regularly repeated at 15 days intervals during the growing season. Fungicide Acrobat MZ 69\% WP (Dimethamorph + Mancozeb) was used as a foliar treatment 60 days after transplanting, at the rate of $250 \mathrm{~g} / 100 \mathrm{~L}$ for four times at 15 days intervals. The control treatment was sprayed with the same amount of sterilized distilled water.

\subsubsection{Downy mildew and onion bulb yield assessments}

Downy mildew severity was recorded at 90 days after transplanting (during the first week of March). One hundred leaves from plants were randomly collected to estimate disease severity in each plot and were recorded using (0-8) scale according to the method described by Townsend and Heuberger (1943).

Disease severity index (\%D.S.I.) and Disease percentage (\% D.P.) of downy mildew were estimated using the following formula:

$$
\text { D.S.I. } \%=\frac{\sum(\mathrm{nxv})}{\mathrm{ZN}} \times 100
$$

D.P. $\%=$ Number of infected leaves/Total number of leaves $\times 100$ 
Where: D.S.I.: $\mathrm{n}=$ Number of leaves in each category, $\mathrm{V}=$ Numerical value of each category, $\mathrm{Z}=$ Numerical value of highest category, and $\mathrm{N}=$ Total number of leaves in the sample. At the end of the season, onion yield was recorded as $\mathrm{Kg} / 100$ bulb.

\subsubsection{Vegetative characteristics determination}

After 120 days from transplanting, ten plants from each replicate were collected randomly to examine vegetative characteristics. This includes fresh leaves length $(\mathrm{cm})$, fresh leaves weight $(\mathrm{gm})$, fresh root length $(\mathrm{cm})$ and fresh root weight $(\mathrm{gm})$.

\subsection{Laboratory experiments and chemical analysis \\ 2.2.1 Sugar determination:}

Carbohydrates were extracted as described by Snell and Snell (1953) and color optical density of the reacted mixture was measured on $540 \mathrm{~nm}$ absorbance using the picric acid technique described by Thomas and Dutcher (1924) and results were expressed as mg/g fresh weight.

\subsubsection{Phenolic content determination}

Total phenols were determined using the Folin-Ciocalteau reagent as mentioned by Snell and Snell (1953). The absorbance was measured at $520 \mathrm{~nm}$ and the phenolic content was expressed as $\mathrm{mg} / \mathrm{g}$ fresh weight.

\subsubsection{Chlorophyll and carotenoids determination}

Determination of chlorophyll A, chlorophyll B and carotenoids content were performed after six weeks of transplanting. Chlorophyll and carotenoids content were determined in $80 \%$ acetone extract. After centrifugation (14.000 rpm, $20 \mathrm{~min}$ ) the absorbance was read spectrophotometrically at 663, 646, 652 and $470 \mathrm{~nm}$, respectively (Hanci and Cebeci, 2014). The concentrations were calculated according to the Lichtenthaler and Welburn (1983) method.

\subsubsection{Enzymatic activity determination}

The activities of the oxidative enzymes, i.e. peroxidase (PO) and polyphenoloxidase (PPO) were determined according to Allam and Hollis (1972) and Matta and Dimond (1963) respectively and assayed using a spectrophotometer at 425 and $495 \mathrm{~nm}$, respectively. The reaction substrates of the oxidative enzymes were pyrogallol, catechol and $\mathrm{H}_{2} \mathrm{O}_{2}$ for determining activity of peroxidase; polyphenoloxidase and catalase, respectively.

\subsection{Statistical analysis}

Obtained data were statistically analyzed by analysis of variance (ANOVA), using "F" test and treatments were compared by L.S.D. at $\mathrm{P}<0.05$ level according to Gomez and Gomez (1984).

\section{Results}

\section{Effect of foliar application of different yeast extract concentrations and Fungicide.}

\subsubsection{Effect on disease severity of onion downy mildew}

The efficiency of application of yeast extracts in comparison to Acrobat fungicide treatment on downy mildew disease severity of onion plants was evaluated under natural field conditions during two successive seasons, 2017/2018 and 2018/2019.

Results in Table (1) indicated that all treatments had positive effects on decreasing downy mildew severity when compared to control. In the first season, the efficiency of foliar application of yeasts showed clear activity of yeasts against downy mildew. Acrobat MZ 69\% fungicide (WP $2.5 \mathrm{~g} / \mathrm{L}$ ) had the superior effect against downy mildew followed by yeast extract $(10 \mathrm{~g} / \mathrm{L})$ which reduced disease severity with the averages of 89.52 and $65.27 \%$ compared to control, respectively. Concerning the percentage, the fungicide application reduced downy mildew disease percentage significantly $14.45 \%$, meanwhile, yeast extract at 5 and $10 \mathrm{~g} / \mathrm{L}$ recorded 51.11 and $41.11 \%$ disease percentage compared to untreated control respectively. Data obtained in second season showed the same pattern. Generally, the reduction in disease severity was directly proportional to the increase in concentration of yeast extracts. 
Table 1: Effect of foliar application of yeast extracts on disease severity and disease percentage of downy mildew under field conditions at Qalyubia governorate during 2017/2018 and 2018/2019 seasons.

\begin{tabular}{|c|c|c|c|c|c|c|c|c|}
\hline \multirow{3}{*}{ Treatments } & \multicolumn{4}{|c|}{$2017 / 2018$} & \multicolumn{4}{|c|}{ 2018/2019 } \\
\hline & Disease & $\%$ & disease & $\%$ & Disease & $\%$ & Disease & $\%$ \\
\hline & severity & Reduction & percentage & Reduction & severity & Reduction & percentage & Reduction \\
\hline Yeast extract $(1 \mathrm{~g} / \mathrm{L})$ & 34.92 & 50.30 & 59.99 & 37.22 & 31.97 & 52.70 & 51.33 & 35.24 \\
\hline Yeast extract $(2 \mathrm{~g} / \mathrm{L})$ & 28.95 & 58.79 & 48.89 & 48.83 & 26.76 & 60.54 & 53.88 & 32.02 \\
\hline Yeast extract $(5 \mathrm{~g} / \mathrm{L})$ & 25.8 & 63.28 & 51.11 & 46.51 & 23.21 & 65.67 & 51.11 & 35.52 \\
\hline Yeast extract $(10 \mathrm{~g} / \mathrm{L})$ & 24.4 & 65.27 & 41.11 & 56.97 & 22.74 & 66.36 & 47.22 & 40.42 \\
\hline Fungicide & 7.36 & 89.52 & 14.45 & 84.88 & 6.28 & 90.71 & 12.78 & 83.87 \\
\hline Control & 70.26 & --- & 95.55 & ---- & 64.92 & ---- & 79.26 & \\
\hline L.S.D at 5\% & 13.4 & & 16.46 & & 8.29 & & 10.96 & \\
\hline
\end{tabular}

\subsubsection{Effect on vegetative characteristics of onion}

Table (2) shows the effect of yeast foliar application on the examined vegetative characteristics and onion bulb yield were more noticeable with increasing yeast concentrations during the two successive seasons. Obtained results indicated that applied treatments increased all plant growth parameters studied including root length, root weight, leaves length, and leave weight. Generally, application of yeast led to significant differences in growth parameters during both seasons.

In the first season, the highest value of leaves weight and leaves length was found using yeast at $10 \mathrm{~g} / \mathrm{L}$ with an average of $81.09 \mathrm{~g}$. and $57.13 \mathrm{~cm}$, respectively.

Table 2: Effect of foliar application of yeast extract on onion vegetative characteristics and yield under field conditions at Qalyubia governorate during the first season.

\begin{tabular}{|c|c|c|c|c|c|c|}
\hline \multicolumn{7}{|c|}{ First season $(2017 / 2018)$} \\
\hline \multirow[t]{2}{*}{ Treatments } & \multicolumn{2}{|c|}{ Length (cm) of } & \multicolumn{2}{|c|}{ Weight (g) of } & \multirow{2}{*}{$\begin{array}{c}100 \text { bulb } \\
\text { weight(Kg) }\end{array}$} & \multirow{2}{*}{$\begin{array}{c}\text { Increase of yield } \\
(\%)\end{array}$} \\
\hline & Leaves & Root & Leaves & Root & & \\
\hline Yeast extract $(1 \mathrm{~g} / \mathrm{L})$ & 51.43 & 5.82 & 53.21 & 2.78 & 15.11 & 12.59 \\
\hline Yeast extract $(2 \mathrm{~g} / \mathrm{L})$ & 51.52 & 8.81 & 62.15 & 3.10 & 15.76 & 17.44 \\
\hline Yeast extract $(5 \mathrm{~g} / \mathrm{L})$ & 51.82 & 10.44 & 69.29 & 3.70 & 17.61 & 31.22 \\
\hline Yeast extract $(10 \mathrm{~g} / \mathrm{L})$ & 57.13 & 11.00 & 81.09 & 4.06 & 18.17 & 35.39 \\
\hline Fungicide & 42.30 & 8.50 & 57.50 & 4.47 & 22.67 & 68.92 \\
\hline Control & 51.81 & 5.72 & 56.67 & 2.87 & 13.42 & 0.0 \\
\hline L.S.D at $5 \%$ & 6.59 & 1.85 & 2.33 & 0.99 & 4.85 & \\
\hline
\end{tabular}

In the second season, yeast $(10 \mathrm{~g} / \mathrm{L})$ increased leaves weight and leaves length to $88.43 \mathrm{~g}$. and $61.25 \mathrm{~cm}$, respectively (Table 3$)$. On the other hand, as a result of using $(10 \mathrm{~g} / \mathrm{L})$ yeast, root length and weight were more than two-fold increase in both seasons, indicating enhanced cell division rate and cell enlargement.

Table 3: Effect of foliar application of yeast extract on onion vegetative characteristics and yield under field conditions at Qalyubia governorate during the second season.

\begin{tabular}{|c|c|c|c|c|c|c|}
\hline \multicolumn{7}{|c|}{ Second season $(2018 / 2019)$} \\
\hline \multirow{2}{*}{ Treatments } & \multicolumn{2}{|c|}{ Length (cm) } & \multicolumn{2}{|c|}{ Weight (g) } & \multirow{2}{*}{$\begin{array}{c}100 \text { bulb weight } \\
(\mathrm{Kg})\end{array}$} & \multirow{2}{*}{$\begin{array}{c}\text { Increase of yield } \\
(\%)\end{array}$} \\
\hline & Leaves & Root & Leaves & Root & & \\
\hline Yeast extract $(1 \mathrm{~g} / \mathrm{L})$ & 55.00 & 6.80 & 58.28 & 3.61 & 16.9 & 9.43 \\
\hline Yeast extract $(2 \mathrm{~g} / \mathrm{L})$ & 55.55 & 10.25 & 69.08 & 4.70 & 17.20 & 15.55 \\
\hline Yeast extract $(5 \mathrm{~g} / \mathrm{L})$ & 56.80 & 11.25 & 76.67 & 4.75 & 19.26 & 36.11 \\
\hline Yeast extract $(10 \mathrm{~g} / \mathrm{L})$ & 61.25 & 12.35 & 88.43 & 4.84 & 19.95 & 40.98 \\
\hline Fungicide & 47.65 & 10.15 & 67.95 & 4.76 & 23.45 & 65.72 \\
\hline Control & 52.36 & 5.91 & 59.36 & 3.67 & 14.15 & 0.0 \\
\hline L.S.D at 5\% & 1.93 & 2.56 & 5.33 & 0.96 & 2.82 & \\
\hline
\end{tabular}

As for root length and root weight, foliar application of yeast with concentrations of 5 and $10 \mathrm{~g} / \mathrm{L}$ showed nearly two-fold increase in each of the two seasons compared with control. Nevertheless, the fungicide did not show same effect meanwhile, it showed the highest effect of yield increases (68.92 
and $65.72 \%$ ) during 2017/2018 and 2018/2019, respectively. Foliar application of any of the different yeast concentrations led to increments in onion vegetative characteristics and bulb yield.

\subsection{Effect of foliar application of yeast extracts and fungicide treatment on biochemical changes of onion plants}

3.2.1. Effect on phenolic contents of onion under field conditions during 2017/2018 and 2018/2019 seasons

Table (4) revealed that phenolic contents including free, conjugated, and total phenols noticeably increased in all treatments compared to untreated control in the two growing seasons 2017/2018 and 2018/2019. In the two growing seasons, data clearly indicate that the highest total phenolic content was initiated by yeast extract treatment at the concentration of $10 \mathrm{~g} / \mathrm{L}(22.73$ and 19.10 , respectively). This was followed by $5 \mathrm{~g} / \mathrm{L}$ (19.30 and 18.73, respectively). Meanwhile, fungicide was the third (16.00 and 16.82 , respectively) compared with untreated control (9.91 and 10.45, respectively).

Table 4: Effect of foliar application of yeast extract on onion phenolic contents under field conditions during 2017/2018 and 2018/2019 seasons.

\begin{tabular}{lcccccc}
\hline & \multicolumn{3}{c}{ First season (2017/2018) } & \multicolumn{3}{c}{ Second season (2018/2019) } \\
\hline & \multicolumn{3}{c}{ Phenol components (mg/g fresh weight/min) } \\
\cline { 2 - 7 } Treatments & $\begin{array}{c}\text { Total } \\
\text { Phenols }\end{array}$ & $\begin{array}{c}\text { Conjugated } \\
\text { phenols }\end{array}$ & $\begin{array}{c}\text { Free } \\
\text { phenol }\end{array}$ & $\begin{array}{c}\text { Total } \\
\text { phenols }\end{array}$ & $\begin{array}{c}\text { Conjugated } \\
\text { phenols }\end{array}$ & $\begin{array}{c}\text { Free } \\
\text { phenol }\end{array}$ \\
\hline Yeast extract (1 g/L) & 9.10 & 0.4 & 8.66 & 14.49 & 4.36 & 10.13 \\
Yeast extract (2 g/L) & 12.05 & 1.16 & 10.89 & 16.79 & 4.22 & 12.57 \\
Yeast extract (5 g/L) & 19.30 & 6.06 & 13.24 & 18.73 & 7.39 & 11.34 \\
Yeast extract (10 g/L) & 22.73 & 8.07 & 14.66 & 19.10 & 7.53 & 11.54 \\
Fungicide & 16.00 & 4.64 & 11.36 & 16.82 & 5.15 & 11.67 \\
Control & 9.91 & 3.05 & 6.86 & 10.45 & 2.56 & 7.89 \\
L.S.D at 5\% & 2.91 & 1.77 & 2.18 & 1.39 & 0.15 & 0.85 \\
\hline
\end{tabular}

3.2.2. Effect on reducing and non-reducing sugar contents of onion under field conditions during 2017/2018 and 2018/2019 seasons.

Effects of different concentrations of yeast extract illustrated in Figure (1) indicated that all treatments of foliar application of yeast resulted in higher values of reducing and non-reducing sugars contents. The highest values of total sugars content were noticed with fungicide followed by concentration of $10 \mathrm{~g} / \mathrm{L}$ of yeast extracts (294 and 215, respectively for the first season and 329 and 232 , respectively for the second season). The control treatments in the two seasons recorded the lowest values of total sugar contents (115 and 123, respectively). The other treatments gave moderate reducing and non-reducing sugars values with remarkable differences in both seasons.
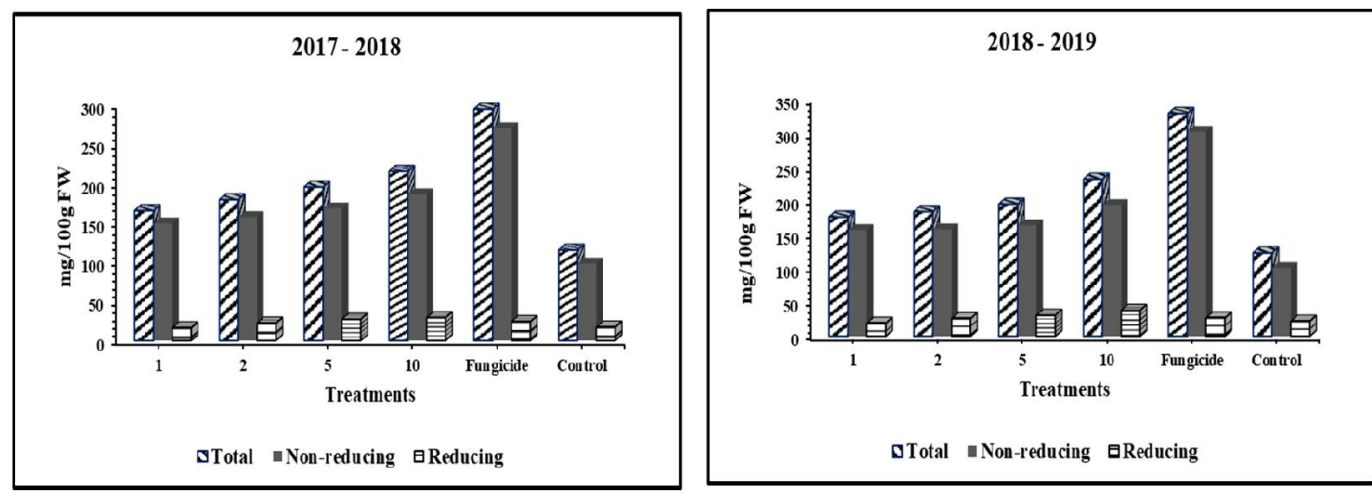

Fig. 1: Effect of foliar application of yeast extract concentrations on onion sugar contents during 2017/2018 and 2018/2019 seasons. 
2.3.2. Effect on photosynthetic pigments of onion under field conditions during $2017 \backslash 2018$ and $2018 \backslash 2019$ seasons.

Figure (2) shows the effect of yeast treatments on photosynthetic pigments. Yeast extract treatments during the two seasons 2017/2018 and 2018/2019 were found to be effective in increasing Chlorophyll A, Chlorophyll B, Chlorophyll A + B and carotenoids concentrations in onion leaves. Yeast extract treatment at concentration of $10 \mathrm{~g} / \mathrm{L}$ and fungicide gave close effects on Chlorophyll $\mathrm{A}$ in both growing seasons. In the case of carotinoides, Yeast extract with concentration of $10 \mathrm{~g} / \mathrm{L}$ had the highest values over the two growing seasons (17.882 and 19.211, respectively), followed by the fungicide (17.08 and 18.9, respectively). In general, significant increase was found on the activity of onion photosynthetic pigments compared with control.
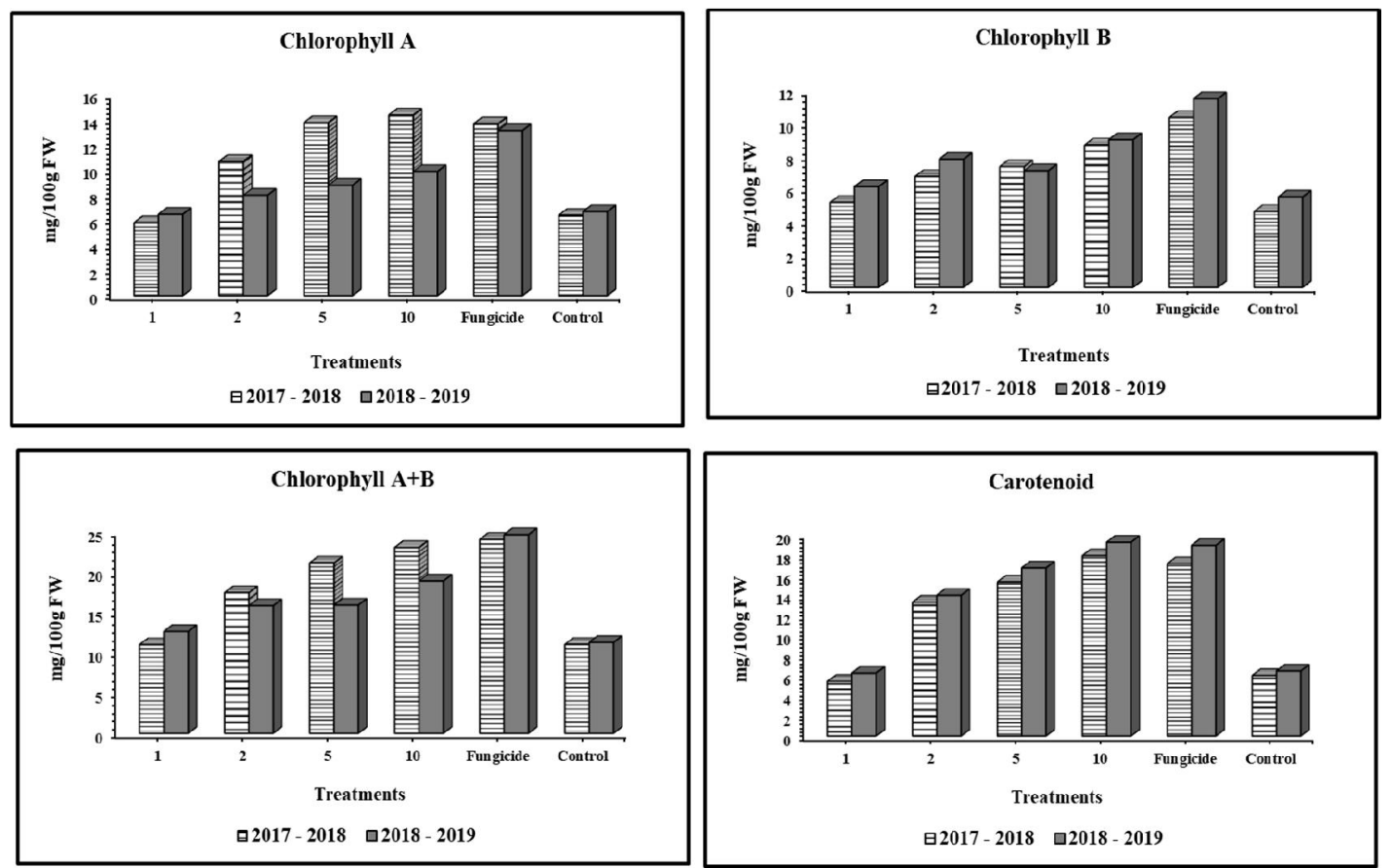

Fig. 2: Effect of foliar application of yeast extract concentrations on onion photosynthetic pigments during 2017/2018 and 2018/2019 seasons.

\subsection{Effect on oxidative enzymes of onion under field conditions during 2017/2018 and 2018/2019 seasons.}

Regarding oxidative enzymes evaluation, table (5) showed that the highest effects were encouraged by yeast extract at a high concentration of $10 \mathrm{~g} / \mathrm{L}$. The data also clarified that both polyphenol oxidase and peroxidase activities were increased ( 0.943 and 2.881) respectively. However, all concentrations of yeast and fungicide treatments showed an increase in oxidative enzyme activity compared with control during the two growing seasons 2017/2018 and 2018/2019.

Table 5: Effect of foliar application of yeast extracts on onion enzymatic activity under field conditions during 2017/2018 and 2018/2019 seasons.

\begin{tabular}{|c|c|c|c|c|}
\hline \multirow{3}{*}{ Treatments } & \multicolumn{2}{|c|}{ First season $(2017 / 2018)$} & \multicolumn{2}{|c|}{ Second season $(2018 / 2019)$} \\
\hline & \multicolumn{4}{|c|}{ The oxidative enzymes (mg/g fresh weight/min) } \\
\hline & Peroxidase & Polyphenoloxidase & Peroxidase & Polyphenoloxidase \\
\hline Yeast extract $(1 \mathrm{~g} / \mathrm{L})$ & 2.129 & 0.717 & 2.751 & 0.908 \\
\hline Yeast extract $(2 \mathrm{~g} / \mathrm{L})$ & 2.542 & 0.767 & 2.998 & 0.917 \\
\hline Yeast extract $(5 \mathrm{~g} / \mathrm{L})$ & 2.793 & 0.779 & 3.157 & 1.112 \\
\hline Yeast extract $(10 \mathrm{~g} / \mathrm{L})$ & 2.881 & 0.943 & 3.265 & 1.211 \\
\hline Fungicide & 1.145 & 0.596 & 2.662 & 0.908 \\
\hline Control & 0.956 & 0.427 & 1.873 & 0.661 \\
\hline L.S.D at $5 \%$ & 0.698 & 0.174 & 0.684 & 0.131 \\
\hline
\end{tabular}




\section{Discussion}

Biological control is explained as non-chemical and environmentally friendly methods for controlling plant diseases by the utilization of natural control agents. Saccharomyces cescervisiae is considered a good promising plant growth promoter for different crops. It became, in the last few decades, a positive alternative to chemical fertilizers safely used for humans, animals, and the environment (Shalaby and El-Nady, 2008). The application of yeasts as biocontrol agents against different pathogens has witnessed a recent rise in interest. Their potential use as biocontrol agents of fungal plant pathogens and as plant growth promoters. Moreover, a wide variety of yeasts have been used extensively for the biological control of mildews diseases (El-Tarabily and Sivasithamparam, 2006).

Active dry yeast (Saccharomyces cerevisiae) is a natural safe biofertilizer which is commonly added to soil or used as a foliar application on different crops because of their bioactivity and safety for human and the environment (Dawood et al., 2019). It has been reported to be a rich source of phytohormones (especially cytokinins), carbohydrates, protein, vitamins, enzymes, amino acids, and minerals. It induces the nucleicacid synthesis, chlorophyll formation, cell division, and enlargement with protective role against environmental stress (Lonhienne et al., 2014).

In the present study, results indicate that all the tested treatments of yeast extract significantly reduced downy mildew disease severity on onion plants, consequently increased the bulb yield during the two successive seasons 2017/2018 and 2018/2019 compared to untreated control. This agrees with Hassan and Abd El-Rehim (2002) who reported that increasing yeast concentration (0.05 to $0.1 \%)$ resulted in gradual reduction to onion neck rot.

The mechanism of yeast as a biocontrol agent involves nutrient competition, site exclusion direct parasitism, and perhaps induced disease resistance (Wisniewski and Droby, 2012).

Yeast extract as foliar spray used to treat garlic and onion plants had a noteworthy effect on vegetative growth, yield and its components as well as bulb quality. The enhancing effect of yeast on the vegetative growth parameters might be due to yeast cytokinins enhancing the accumulation of soluble metabolites (Ahmed, 2015; Shafeek et al., 2015). Increasing vegetative growth parameters may be due to the content of yeast extract which includes valuable components such as polysaccharides, alginates, polyamines, amino acids, nutrients, natural cytokinins, auxins and auxin-like compounds and gibberellins which affect cells metabolism processes which in turn encourage the plant vegetative growth (Olaiya, 2010). These studies are supporting present data which clarified that foliar application of yeast extract treatment specially at a concentration of $10 \mathrm{~g} / \mathrm{L}$ resulted in an increase in shoot and root fresh weight in comparison to the control. In this respect, current results were found to be in harmony with those obtained by Shalaby and El-Ramady (2014) on garlic, and Shafeek et al., (2015) on onion plants. Also, Fawzy et al., (2012) reported that foliar application of onion plants by yeast extracts significantly increased the vegetative growth characteristics of fresh weight for both leaves and bulbs. These increments were gradual and consistent with increasing the concentrations of yeast. Similarly, the increase of average weight of bulb of onion plants was mainly attributed to the increase in total yield per plant which was enhanced by these treatments.

In this study, the application of Acrobat MZ 69\% fungicide significantly increased yield although the vegetative characteristics of the plants were less than the effect of the yeast treatments. This is in harmony with the work carried out by Araújo and Resende (2020) who stated that the constant presence of a protective Ridomil fungicide on onion leaf surface can prevent infections and reinfections. Therefore, the protective action of fungicide may be due to the direct contact between the fungicide and the pathogen that increases the thickness of onion leaves, which leads to healthy plants capable of photosynthesis and food processing (Farouk et al., 2008). Meanwhile, increasing the vegetative characteristics using yeast treatments is due to the stimulating effect of yeast inside plants such as activating cell division and other physiological processes.

The obtained results are in coincidence with Abd AL-Razaq (2019); Pyakurel et al., (2019); Dawood et al., (2019), who mentioned that treated plants with a mixture of yeast extract as an independent factor showed a significant increase in yield. The increase of yield with application of yeast is related to natural phytohormones contents in the extracts, mainly cytokinin and other components (Lonhienne et al., 2014). In this regard, the increase in plant yield may be explained as a result of great vegetative growth as previously mentioned. 
On the other side, our results clarified that all yeast concentrations used showed considerable increase in phenolic content during the two seasons. These results are in agreement with Gawlik-Dziki et al., (2013) they detected changes in the phenolic profile of treated broccoli sprouts; which was elevated by yeast spraying; resulting in increased antiradical activity of the broccoli sprouts. An increase of total phenols was also experienced by Abbdallah et al., (2016) on onion.

The present study also proved that an increase in pigments formation of Chlorophyll A, B, A + $\mathrm{B}$ and carotenoids was associated with increasing yeast concentration used during the two growing seasons. Similar results were recorded by Nemeat Alla et al., (2015) they stated that foliar application of yeast increased leaf pigment contents of sugar beet. Such increase in photosynthetic pigments formation could be attributed to the role of yeast cytokinins delaying the aging of leaves by reducing the degradation of chlorophyll and enhancing the protein and RNA synthesis (Glick, 1995). In this regard, the enhancement of yeast application on leaf pigment contents might be due to the delay of leaf senescence by decreasing leaf pigments decomposition or by improving its biosynthesis (Dawood et al., 2019). Moreover, this is proved by Khalil and Ismael (2010) they applied foliar and soil, as well as combined treatments and found that foliar application of yeast extract is significantly more effective on the chlorophyll content of leaves than soil inoculation. These results are in accordance with those documented by Wanas (2006) and Mahmoud et al., (2020) they reported that, yeast extract had a stimulatory effect on several processes in plants such as cell division, chlorophyll formation, synthesis of protein, and nucleic acid.

Foliar application of yeast also affected the measured reducing and non-reducing sugars, which increased gradually when concentration was increased. The same result was observed by El-Shafey et al., (2016) and Hammad and Ali (2014).

Based on our results, both of polyphenol oxidase and peroxidase enzyme activities were increased at all concentrations of yeast treatment used and fungicide compared with control. This increase may be due to a positive relationship between oxidative activity and resistance developed in plants (Mohammadi and Kazemi, 2002). Furthermore, the activity of peroxides and polyphenol oxidase increases by using the highest concentration of yeast extract $(10 \mathrm{~g} / \mathrm{L})$. This agrees with Abou-Taleb (2001) and Mosa (2002) they reported that bioagents can enhance the activities of the defense-related enzymes such as chitinase and peroxidase.

In conclusion, the present study suggests that foliar application of Saccharomyces cescervisiae has proven effective in both controlling downy mildew disease in onion and enhancing yield and quality production of onion plants. One of the several factors in favor of using yeast extracts as bioagents is that they can be implemented efficiently in biocontrol, due to their multiple modes of action, rapid growth, a low cost compared to synthetic fungicides, and being safe for human consumption.

\section{References}

Abdallah, S.B., B. Aung, L. Amyot, I. Lalin, M. LachâaL, and N. Karray-Bouraoui, 2016. Salt stress $(\mathrm{NaCl})$ affects plant growth and branch pathways of carotenoid and flavonoid biosyntheses in Solanum nigrum. Acta Physiologiae Plantarum, 38(3): 1-13.

Abd AL-Razaq, A.H., 2019. Whey applications in plants. Plant Archives. 19 (1): 45-48.

Abou-Taleb, Mona M.A., 2001. Biochemical changes associated with the application of some resistance inducing compounds for controlling powdery mildew of cucumber. Egypt. J. Appl. Sci., 6(12): 387-405.

Ahmed, M.E.M., 2015. Response of garlic plants (Allium sativum L.) to foliar application of some bioStimulants. Egypt. J. Hort., 42(1): 613-625.

Allam, A.I. and J.P. Hollis, 1972. Sulfide inhibition of oxidase in rice root. Phytopathology, 62,634636.

Anonymous, 2018. Statistical Dep. of Ministry of Agric. \& land Rec., El-Giza, Egypt.

Ankita, S. Chandel, R. Sharma, and V.K. Meena, 2020. Epidemiological Studies of Downy Mildew of Onion. Int. J. Curr. Microbiol. App. Sci. 9(5): 1-12.

Araújo E.R. and R.S. Resende, 2020. Propineb efficiency in controlling downy mildew of onion under field conditions. Aust. Pl. Dis. Notes.1-4.

Bekatorou A., C. Psarianos and A.A. Koutinas, 2006. Production of food grade yeasts. Food Tech.Biotec., 44:407-415. 
Dawood, M.G., M. Sh. Sadak, M.M.S. Abdallah, B.A. Bakry, and O.M. Darwish, 2019. Influence of biofertilizers on growth and some biochemical aspects of flax cultivars grown under sandy soil conditions. Bull. of the Nat. Res. Cen. 43(81): 2-13.

El-Sayed, H.E. Z., and E.S.H. Farrag, 2011. Application of yeasts as biocontrol agents for controlling foliar diseases on sugar beet plants. Agric. Tech. 7(6): 1789-1799.

El-Shafey, A.I., S.S. El-Feky, and S.A. Abo-Hamad, 2016. Effect of sowing time and foliar application of yeast extract on growth and productivity of different cultivars of faba bean (Vicia faba L.). Egypt J. Bo., 56: 35-48.

El-Sharkawy, H.H.A., S. Tohamey, and A.A. Khalil, 2015. Combined effects of Streptomyces viridosporus and Trichoderma harzianum on controlling wheat leaf rust caused by Puccinia triticina. Plant Pathol. J., 14: 182-188

El-Tarabily, K.A., and K. Sivasithamparam, 2006. Potential of yeasts as biocontrol agents of soil-borne fungal plant pathogens and as plant growth promoters. Mycoscience, 47:25-35.

EFSA (European Food Safety Authority). 2005. Opinion of the scientific committee on a request from EFSA related to a generic approach to the safety assessment by EFSA of microorganisms used in food/ feed and the production of food/feed additives. EFSA J 3:226.

Farouk, S., K.M. Ghoneem, and A.A. Ali 2008. Induction and expression of systemic resistance to downy mildew disease in cucumber by elicitors. Egy. J. Phytopath., 36, (1-2) 95-111.

Fawzy, Z. F., M.M. Abou El-magd, L. Yunsheng, Z. Zhu Ouyang, and A.M. Hoda, 2012. Influence of foliar application by EM "effective microorganisms", amino acids and yeast on growth, yield and quality of two cultivars of onion plants under newly reclaimed soil. J. of Agric. Sci., 11(4): 26-39.

Gawlik-Dziki, U., M. Świeca, D. Dziki, B. Baraniak, J. Tomiło, and J. Czyż, 2013. Quality and antioxidant properties of breads enriched with dry onion (Allium cepa L.) Food Chem. 138 (2012) 1621-1628.

Glick, B.R., 1995. The enhancement of plant growth by free living bacteria. Cand. J. Microbiology, 41: 109-117.

Gomez, K.A., and A.A. Gomez, 1984. Statistical Procedures for Agricultural Research. $2^{\text {nd }}$ ed. 680 PP. John Wiley Sons. New York. U.S.A.

Gupta, C., D. Prakash, P.A Garg and S. Gupta, 2012. Whey protein: A novel source of bioceuticals. Middle East J. Sci. Res., 12(3): 365375.

Hanci, F., and E. Cebeci, 2014. Investigation of proline, chlorophyll and carotenoids changes under drought stress in some onion (Allium Cepa L.) cultivars. Turk. J. of Agric. and Nat. Sci. Special, 2: $1499-1504$.

Hammad, S.A.R., and O.A.M. Ali, 2014. Physiological and biochemical studies on drought tolerance of wheat plants by application of amino acids and yeast extract. Ann. of Agric. Sci., 59: 133145.

Hassan, M.H.A., and G.H. Abd El-Rehim, 2002. Yeast application as a biofertilizer and biocontrol agent for onion neck rot disease in relation to bulb productivity and quality. Assiut J. Agric. Sci., 33(1): 241- 251.

Khalil, S.E., and E.G. Ismael, 2010. Growth, yield and seed quality of Lupinus termis as affected by different soil moisture levels and different ways of yeast application. J. Am. Sci. 6: 141-153.

Lichtenthaler, K., and A.R. Wlburn, 1983. Determination of total carotenoids and chlorophylls a and b of leaf extracts in different solvents. Biochem. Soci. Transact., 11(5): 591-592.

Lonhienne, T., G.M. Michael, A.R. Mark, H. Philip, S. Susanne, and Ch.P. Lonhienn, 2014. Yeast as a biofertilizer alters plant growth and morphology. Crop science, 54: 785-790.

Matta, A., and C. Dimond, 1963. Symptoms of Fusarium wilt in relation to quantity of fungus and enzyme activity in tomato stems. Phytopathology, 53: 574-587.

Mahmoud, S.H., A.M.M. El-Tanahy, and Z.F. Fawzy, 2020. The effects of exogenous application of some bio stimulant substances on growth, physical parameters and endogenous components of onion plants. Inter. J. of Agric. and Earth Sci., 6(2): 1-13.

Nemeat Alla, H.E.A., D.I.H. El-Geddawy, and B.S.I. Makhlouf, 2015. Effect of yeast application method and number on yield and quality of sugar beet under different levels of nitrogen. $\mathrm{J}$. Plant Production, Mansoura Univ., 6 (9): 1475 - 1490. 
Mohammadi, M., and H. Kazemi, 2002. Changes in peroxidase and polyphenol oxidase activities in susceptible and resistant wheat heads inoculated with Fusarium graminearum and induced resistance. Plant Science, 162: 491-498.

Morsi, M.K., B. El-Magoli, N.T. Saleh, E.M. El-Hadidy, and H.A. Barakat, 2008. Study of antioxidants and anticancer activity licorice (Glycyrrhiza glabra) extracts. Egyptian J. Nutr. and Feeds, 2(33): 177-203.

Mosa, A.A., 2002. Induced resistance in rice against blast disease using abiotic and biotic agents. Ann. Agric. Sci., Ain Shams Univ., 47: 993-1008.

Olaiya, C.O., 2010. Presowing bioregulator seed treatments increase the seedling growth and yield of tomato (Lycopersicon esculentum). J. Plant Growth Regul., 29: 349-356.

Pyakurel, A., B.R. Dahal, and R. Swodesh, 2019. Effect of molasses and organic fertilizer in soil fertility and yield of spinach in Khotang, Nepal. Int. J. Appl. Sci. Biotechnol., 7(1): 49-53.

Schwartz, H.F., and S.K. Mohan, 2008. Compendium of onion and garlic diseases. St. Paul: APS. 127.

Shafeek, M.R., Y.I. Helmy, and N.M. Omar, 2015. Use of some bio-stimulants for improving the growth, yield and bulb quality of onion plants (Allium cepa L.) under sandy soil conditions. Middle East J. of App. Sci. 5(1): 68-75.

Shalaby, M.E., and M.F. El-Nady, 2008. Application of Saccharomyces cerevisiae as a biocontrol agent against Fusarium infection of sugar beet plants. Acta Biological Szegediensis, 52(2): 271-275.

Shalaby, T.A., and H. El-Ramady, 2014. Effect of foliar application of bio-stimulants on growth, yield, components, and storability of garlic (Allium sativum L.). Aust. J. Crop. Sci., 8 (2): 271-27.7183.

Sharma, R.C., S.S. Gill, and N. Kohli, 2002. Pathological problems in production and storage of onion seed in Punjab and their remedial measures. Seed Research, 30: 134-141.

Snell, F.D., and C.I. Snell, 1953. " Colorimetric Methods". Vol. III. D. Van Nostrand Co. Inc., Torento, N. Y., London, 606 p.

Spadaro, D., and S. Droby, 2016. Development of biocontrol products for postharvest diseases of fruit: the importance of elucidating the mechanisms of action of yeast antagonists. Trends Food Sci. Technol., 47: 39-49.

Suleria, H.A., M.S. Butt, F.M. Anjum, F. Saeed, and N. Khalid, 2015. Onion: nature protection against physiological threats. Critical. Rev. Food Sci. Nutr., 55(1): 50-66.

Thomas, W., and R.A. Dutcher, 1924. The Colorimetric determination of carbohydrates methods. J. Amr. Chem. Soc., 46: 1662 - 1669.

Townsend, G.R., and J.W. Heuberger, 1943. Methods for estimating losses caused by diseases in fungicide experiments. Pl. Dis. Rep., 27: 340-343.

Wanas, A.L., 2006. Trails for improving growth and productivity of tomato plants grown in winter. Annals. Agric. Sci. Moshtohor, 44(3): 466-471.

Wisniewski, M., and S. Droby, 2012. Biopreservation of food and feed by postharvest biocontrol with microorganisms. In: Sundh, I., Wilcks, A., and Goettel, M. S. (eds) Benefcial microorganisms in agriculture, food and the environment. CABI International, Oxfordshire, 57-66

Yousef, H., 2021. Integration of bioagents with antioxidants to control Powdery Mildew disease in sunflower. Egyptian Journal of Agricultural Research. Egypt. J. Agric. Res., 99 (2): 158-169. 